\title{
Effect of School Environment on Students' Commitment toward Learning among Secondary Schools in Monduli District, Tanzania
}

\author{
Furahini Godson* and Baraka M. Ngussa, PhD \\ University of Arusha \\ Correspondence: godsonfurahini36@gmail.com
}

\begin{abstract}
This study sought to investigate the effect of school environment on students' commitment toward learning among Secondary Schools in Monduli District, Tanzania. The study employed the quantitative approach in collecting and analyzing data from 346 respondents across five secondary schools in the District. The findings revealed that students' perception were negative on the school environment as they tended to disagreed with the items. The study further indicates that students were committed toward learning. Finally, the study established the existing relationship between school environment and students' commitment toward learning. Therefore, effective school environment predicts the rate of students' commitment toward learning. The study therefore recommends that school management teams should work hard to improve the identified school environment factors as the factors are essential for effective learning to take place. The identified students' commitment toward learning needs to be rewarded for students to maintain such a spirit as it is a key factor for effective learning to take place. Furthermore, school administrators should find ways to create conducive learning environment.
\end{abstract}

Key words: School Environmental Factors, commitment, learning, Monduli, Tanzania

\section{Introduction}

School environment has been defined by various authors in various ways. Mege (2014.p.xiii), for instance, defined it as "factors within the school that influence the teaching and learning process. The school environment includes classrooms, library, technical workshops, teachers' quality, teaching methods, peers, among others that can affect the teaching and learning process." This definition implies that there are various school environmental variables and these may differ from one school to another. Korir and Kipkemboi (2014) postulate that school environmental factors include school structure, school composition and school climate. In addition, school environmental factors may also include safety and order, teacher relationships and collaboration, academic expectations, leadership and teachers' professional development factors.
Variation of school environment is brought to view by Mege (2014) who conducted a study in Kenya and postulates that;

The location of the school has an effect on the teaching-learning process. Most schools in the urban areas are well staffed as compared to those in rural areas since everyone wants to work in the urban centers due to the technology which is high in the urban areas as compared to the rural areas (p.19).

Studies have indicated that school environment can determine the students' Commitment towards learning. A study done in Zimbabwe, for instance, by Nyoni, Nyoni and Bonga (2017) established that school environment promote students' commitment toward learning as proper school environment makes the students psychologically comfortable and enhances students' motivation in school related 
activities, making learning efficient and interesting. The findings further indicate that teaching and learning become easy when students are committed due to being comfortable with the school environment. The findings also revealed that availability of resources play an important role in determining learning effectiveness. Similarly, the study done in Kenya by Nambuya (2013) revealed that provision of adequate learning facilities including equipment and human resources enhances the quality and relevance of imparted skills to learners. This is because learning involves interaction of students with the environment which includes the quality of classrooms, laboratories, libraries, playing fields and textbooks, among others. Indeed, physical resources go long way in creating conducive environment that promotes students' commitment toward learning.

Lee (2014) on exploring learning environmental factors that affect student cognitive engagement has it that, relationships exists between students' commitment towards learning and school environmental factors. The findings further revealed that when the school environmental factors are good, teaching and learning become effective and attract student's participation since students will be comfortable in their learning process. A study by UNESCO (2016) in Benin, Congo and Ghana revealed that the availability of electricity and sanitation facilities improves the learning environment and students 'health, boosting school attendance and facilitating school activities and in that way improves students' commitment toward learning. While there are numerous benefits of school environment toward learning effectiveness, this study sought to establish the correlation between school environment and students' commitment toward Learning.

According to Ngussa and Nzowa (2019), commitment toward learning is an additive function related to academic and school issues. They further argue that commitment is influenced among others by school environmental factor and that commitment enhances students' success. Oblinger (2010) on the other hand, considers commitment toward learning as beyond the acquisition of knowledge and skills but to include ability to think critically and solve complex problems, work collaboratively, communicate effectively and pursue self-directed learning or metacognition. Therefore, commitment towards learning focuses on the behavior of the students in the whole process of leaning.

School environmental factors have been demonstrated to have significant impact in the whole process of teaching and learning. It plays an important role in the cognitive, affective and social domains of students because these factors have direct and indirect impact such as creating positive impact on students toward learning, enhancing participation in the process of learning and promoting students' commitment towards learning, which in turn results into good academic progress. Therefore, school environmental factors are extremely important as they affect the way students learn (Mustapha, 2014). A study done in New York City schools by Learning Liftoff (2016) reveals that those students who attend safe schools where they are expected to form positive relationships with their teachers and peers have a notable advantage over students who attend schools without these beneficial traits. He further revealed that, in New York City schools, the issue of physical school environmental factor is not a serious problem due to the economic stability and good educational systems.

In Malysia, a study by Usaini, Abubakar and Bichi (2015) revealed that, school environment has a broad influence on the students learning and growth including social, emotional and ethical development. The findings further show that when the school environment is supportive and caring, it fosters the students' sense of connectedness and belongingness which in turn fosters their academic success. The Ministry of Education, Guyana (2016) also pointed out that, creating a positive learning environment is essential for success in the school and classroom. Teachers should therefore create a welcoming atmosphere both emotionally and physically where students feel safe and willing to share ideas.

In African countries, the issue of school environmental factors is one of the challenges in schools. The study done by Oden (2019) in Nigeria indicated that the extent to which learning could be committed depends on their location within the school compound, the structure of their classroom, availability of instructional facilities and other related resources. Juan and Visser (2017) who conducted their study in South Africa also revealed the existing strong relationship between the school environmental factors and the whole process of 
teaching and learning. The study further revealed that school environmental factors contributed to the learners' class activeness and the general academic performance.

In Tanzania, a research carried by Haki Elimu (2013) revealed that students' academic performance and commitment towards learning at various levels of education has been attributed by schools' environmental factors such as adequacy of teaching and learning materials like books and laboratories. The study further revealed that safety, relationship of teachers, students and school infrastructures in general were the key tools for students' achievement. The study also revealed that the schools with positive school environment are likely to motivate leaners to learn better and enjoy their schooling. Also a study done at Wanging'ombe District in Tanzania by Ulugumu (2016) revealed that, school environmental factors may influence or affect the students' academic achievement and commitment toward learning. He mentioned some school environmental factors including; teacherstudent ratio, Class size, teaching and learning environments, teaching and learning materials, libraries and laboratories as determinants of students' commitment toward learning.

Secondary schools in Monduli District are in poor conditions as revealed by the study of Mwinuka (2016) in the district which indicated that most of low performing secondary schools do not have enough such infrastructures like classroom and laboratories, dining halls, playgrounds, toilets, desks for students and dormitories. The findings further revealed that the available classrooms were $39 \%$ while $61 \%$ was the shortage. This means that in some schools, students were forced either to learn in overcrowded classrooms or go into shifts. The situation demotivated some students to learn, leading to absenteeism and dropout.

Statistics from Monduli District Education Officer (2019) indicated that from 2016 to 2018, Division One Form Four leavers were 15 (1\%), Division two were 157 (10\%), division three 331 (20\%), division four 851 (52\%) and Division zero were 282 (17\%). It is not clearly known the reasons for poor performance in Secondary schools of Monduli District. While poor performance can be associated with poor studying environment, this study investigated on effect of school environment related factors in relation to students' commitment towards learning in Monduli District.
There are a variety of reasons why policy makers, scholars, educational leaders and teachers associate the school environmental factors with students' commitment toward learning. School environmental factors have been demonstrated to have significant impact in the whole process of teaching and learning, playing an important role in the cognitive, affective and social domains of students because these factors have direct and indirect impact such as creating positive impacts on students toward learning (Ulugumu, 2016).

While efforts have been done by the Government, Private institutions an educational stakeholders to ensure that schools have good environment for learning, students' commitment toward learning in Monduli District is still low. This study therefore, aimed at filling that gap by examining the effect of school environment on students' commitment towards learning among the Secondary Schools in Monduli District. The study was guided by the following research questions:

1. What are the students 'perception on the school environmental factors among Secondary Schools of Monduli District?

2. What is the rate of students' commitment toward learning in Secondary Schools of Monduli District?

3. Is there significant relationship between school environmental factors and students' commitment toward learning?

\section{Research Methodology}

This section provides the description of the research methodology which includes research design, population and sampling procedures, data collection methods, validity, reliability, analysis and results and ethical considerations.

\section{Research Design}

The study adopted the descriptive research design. According to Mugenda and Mugenda (1999), descriptive design is useful as it helps to obtain information that describes the existing phenomena by asking individuals about their perceptions, attitudes and values. The descriptive design was used so as to achieve the main objective of the study which was to examine the effect of school environment on students' commitment towards learning among Secondary Schools in Monduli District. Data was collected through the selfadministered questionnaire. 


\section{Population and Sampling}

Population of the study can be defined as the area to which a researcher wants to generalize the results of the study. Population may involve a larger group of people, institution or things that have one or more characteristics in common on which a study focuses. It consists of all cases of individuals or elements that fit a certain specification (Kothari 2004). The population of students in the selected schools was as follows; Maasae Girls Lutheran secondary school (452), Noonkord in Secondary School (325), Lowassa Secondary School (726),
Irkisongo Secondary School $(1,000)$ and Engutoto Secondary School (997). The total population of students from the five selected secondary schools was 3500. Based on the formula of Krejcie and Morgan (1970), this study used the stratified random sampling techniques to obtain 346 respondents from the five strata. In the five selected secondary schools, the researchers selected a certain number of Form three students. Form Threes were suitable because they had no pressure of national examinations like the form two and form fours.

Table 1: Population and Sampling

\begin{tabular}{lcc}
\hline Selected School & Population Size & Sample size \\
\hline Maasae Girls Lutheran S.S & 452 & $452 / 3500 \times 346=45$ \\
Irkisongo S.S & 1000 & $1000 / 3500 \times 346=99$ \\
Engutoto S.S & 997 & $997 / 3500 \times 346=98$ \\
Lowassa S.S & 726 & $726 / 3500 \times 346=72$ \\
Noonkodin S.S & 325 & $325 / 3500 \times 346=32$ \\
Total & $\mathbf{3 5 0 0}$ & $\mathbf{3 4 6}$ \\
\hline
\end{tabular}

\section{Validity and Reliability}

According to Blerkom (2009), validity refers to whether or not the test measures what it claims to measure. The validity of the questionnaire was done through expert review. The pilot study was conducted in one school within the district which was not part of the sample and the results yielded the Cronbach's Alpha of 0.7 and above in each variable, meaning the instrument was reliable for data collection.

\section{Statistical Treatment of Data}

Data were collected, coded and then entered in the software called SPSS version 22 whereby frequency and percentage were used to analyze the demographic characteristics of respondents and descriptive statistics such as mean and standard deviation were used to analyze data from the first two research questions with the following interpretation: 1:00-1.49= Tend to Disagree, 1:502.49= Disagree, $2.5-3.49=$ Tend to Agree and 3.50$4.00=$ Agree. The third research question was analysed through Pearson Correlation.

\section{Ethical Considerations}

Before data collection took place in the field, the researcher sought permission from Government Authorities. The permission request letter was sent to the Arusha Regional Administrative Secretary then the letter was sent to Monduli District
Administrative Secretary who gave the researchers permission to collect data in a specified period of time. After the permission was granted, the researchers collected data in the field. The researcher ensured that all respondents voluntarily participated in the study and the information collected were kept confidentially and were used for the purpose of the study only.

\section{Analysis and Discussion}

\section{Demographic Profile of Respondents}

This section presents the demographic profile of respondents who filled the questionnaire which was the only instrument used to gather data. While the total number of respondents was 346, only 324 (93.6\%) returned the questionnaires. Respondents were categorized according to gender whereby male students were 145 (44.9\%) while female students were 178 (55.1\%). Therefore, majority of respondents were female students.

\section{Descriptive Analysis}

This part described the perception of students about school environmental factors as well as their commitment towards learning. The section was guided by two research questions as follows:

Research Question 1: What is the perception of students on the school environmental factors among Secondary Schools of Monduli District? 
This research question sought to establish the perception of students toward their school environmental factors. The research question was guided by 15 items from the questionnaire to which students responded as reflected in Table 2.

Table 2: Students' Perception on School Environment

\begin{tabular}{llccc}
\hline SN & \multicolumn{1}{c}{ Questionnaire Items } & Mean & Std. Dev & Interpretation \\
\hline 1 & There is good sanitation at school & 2.20 & .85737 & Tend to Disagree \\
2 & The school environment is safe for students to learn & 2.19 & .94121 & Tend to Disagree \\
3 & There is sound relationship between teachers and students & 2.19 & .95672 & Tend to Disagree \\
4 & The school environment is supportive for learning & 2.16 & 1.02398 & Tend to Disagree \\
5 & The school environment is motivating & 2.15 & .84818 & Tend to Disagree \\
6 & The classroom learning atmosphere is conducive & 2.15 & .86485 & Tend to Disagree \\
7 & There is clean water for students & 2.14 & .95187 & Tend to Disagree \\
8 & The school environment makes learning enjoyable & 2.12 & .90530 & Tend to Disagree \\
9 & There is good teacher-student ratio & 2.12 & .95601 & Tend to Disagree \\
10 & There are sound teaching methods & 2.04 & .93257 & Tend to Disagree \\
11 & There is good student-book ratio & 2.04 & .83592 & Tend to Disagree \\
12 & There is enough and quality laboratories & 2.03 & .84525 & Tend to Disagree \\
13 & There is enough and quality play fields & 1.99 & .82472 & Tend to Disagree \\
14 & There are enough teaching and learning materials & 1.94 & .84297 & Tend to Disagree \\
15 & There is good school infrastructures in general & 1.87 & .87053 & Tend to Disagree \\
\hline
\end{tabular}

Table 3: Students' Commitment toward Learning

\begin{tabular}{llcll}
\hline \multicolumn{1}{c}{ SN } & \multicolumn{1}{c}{ Questionnaire Item } & Mean & Std. Dev & Interpretation \\
\hline 1 & I attend school regularly & 3.17 & .83581 & Tend to Agree \\
2 & My participation in learning has been improving & 2.84 & .91774 & Tend to Agree \\
3 & I am confident in the learning process & 2.75 & 1.00379 & Tend to Agree \\
4 & I have positive attitude toward my school & 2.64 & .93050 & Tend to Agree \\
4 & School time is utilized well by students & 2.61 & .88446 & Tend to Agree \\
6 & I have time to study privately at school & 2.57 & .98283 & Tend to Agree \\
7 & Leaning process is enjoyable & 2.57 & 1.00908 & Tend to Agree \\
8 & I work hard in school related activities & 2.56 & 1.03991 & Tend to Agree \\
9 & I make good use of learning resources at school. & 2.54 & 1.07899 & Tend to Agree \\
10 & I am able to solve my own learning challenges & 2.51 & 1.00966 & Tend to Agree \\
\hline
\end{tabular}

The mean scores for responses to table two ranged between 1.50 and 2.49 which means that students who filled the questionnaire tended to disagree that there is good sanitation at their schools, that the school environment is safe for students to learn, that there is sound relationship between teachers and students and that the school environment is supportive and motivating for learning.

Furthermore, students tended to disagree that the learning atmosphere is conducive, that the studentteacher ratio is fair, that teachers use sound teaching methods, that there are quality laboratories, that there are quality play grounds, that there are sufficient teaching and learning materials and that there is a good school infrastructure in general. Therefore, the feedback from table 2 suggests that students did not consider their leaning environment conducive. The findings of a previous study by Mwinuka (2016) in the same district revealed similar findings that most of low performing secondary schools in the district did not have enough such infrastructures like classroom and laboratories, dining halls, playgrounds, toilets, desks for students and dormitories.

Research Question 2: What is the rate of students' commitment toward learning among Secondary Schools of Monduli District?

This research question sought to establish the level of students' commitment toward learning using 10 items in the questionnaire as seen in Table 3.

The mean scores in all statements were between 2.50 and 3.49 which means students tended to agree with all the statements. Particularly, they tended to agree that they attend school regularly, their participation toward learning has been improving, they are confident in the learning process, they have positive attitude toward learning and they utilize well the school time. Furthermore, 
students tended to agree that they have time to study privately at schools, that the learning time is enjoyable, that they work hard in school related activities, that they make good use of the available resources and that they are able to solve their own learning challenges. The identified rate of students' commitment toward learning is commendable by Ngussa and Nzowa (2019) whose study established that commitment toward learning is an additive function related to academic and school issues.

\section{Hypothesis Testing}

Having determined the perception of students toward school environmental factors and their commitment toward learning, this section tested a hypothesis that resulted from the third research question:

Research Question 3: Is there significant relationship between school environmental factors and students' commitment toward learning?

This research question sought to establish the relationship between school environmental factors and students' commitment toward learning. This question was prompted by Namugaanyi's (2012) assertion that school environment is a set of internal features that differentiate one school from another and that the factors influence the behavior of staff and students. He also argued that the school environment in general plays a vital role in the life of every individual including students and teachers.

The research question called for testing of a null hypothesis which states: there is no significant relationship between school environmental factors and students' commitment toward learning. The hypothesis was tested through Pearson Product Moment Correlation Coefficient as seen in Table 4 which indicates the Pearson Correlation or .480 with the Sig of .000 which denotes that there is a significant moderate positive correlation between School Environmental factors and students' commitment toward learning. Therefore the null hypothesis was rejected. Since this correlation is positive, it means that the better the school environmental factors, the higher the students commitment toward learning. Therefore, effective school environment contribute toward the rate of students' commitment toward learning.

Table 4: Correlation between the Independent and Dependent Variables

\begin{tabular}{llcc}
\hline & & ENVIRONMENTAL & COMMITMENT \\
\hline ENVIRONMENTAL & Pearson Correlation & 1 & $.480^{* *}$ \\
& Sig. (2-tailed) & & .000 \\
COMMITMENT & $\mathrm{N}$ & 323 & 323 \\
& Pearson Correlation & $.480^{* *}$ & 1 \\
& Sig. (2-tailed) & .000 & 323 \\
\hline
\end{tabular}

**. Correlation is significant at the 0.01 level (2-tailed).

This finding is in harmony with that in Sudan by Ahmed, Taha, Al-Neel and Gaffar (2018) that students with higher academic achievement had more positive perceptions regarding the school environmental factors, while low-achieving students exhibited more negative perceptions of school environmental factors. Therefore, the school surrounding must be pleasing to learners for them to be motivated and committed towards learning. Likewise, the study of Kurniawan, Effendi and Dwita (2018) indicated the relationship between school environmental factors and students' commitment towards learning. The study further shows that to a greater extent, school environmental factors have impact on students' commitment towards learning and that students who learn in positive environments are committed than those in poor learning environments.

\section{Conclusions and Recommendations}

This section presents the conclusions of the study and then gives the corresponding recommendations.

\section{Conclusions}

Based on the findings, the study came up with the following conclusion:

1. School environment factors were perceived by students as unconducive for learning effectiveness as students tended to disagree with all statements in the questionnaire regarding school environmental factors. 
2. The rate of students' commitment toward learning was high as students tended to agree with all the items in the questionnaire regarding the rate of their commitment toward learning.

3. Effective school environmental factors positively affects students' commitment toward learning. Therefore, effective school environmental factors need to be manipulated in order to predict the rate of students' commitment toward learning.

\section{Recommendations of the Study}

Based on conclusions, the study came up with the following recommendations:

1. School management teams should work hard to improve the identified school environmental factors as the study revealed that proper school environment is essential for learning to take place.

2. The identified students' commitment toward learning needs to be rewarded for students to maintain such a spirit as it is a key factor for effective learning to take place.

3. It is important for school administrators to work on the identified challenges to create conducive learning environment which has been found to have a positive effect toward students' commitment towards learning.

\section{Reference}

Ahmed, Y. Taha, M.H. Al-Neel, S. and Gaffar, A.M. (2018). Students' perception of the Learning environment and its relation to their study year and performance in Sudan. International Journal of Medical Education 9, 145-150.

Haki Elimu (2013). Does school environment affect students achievements? An investigation on the relationship between secondary schools characteristics and academic performance in Tanzania. Retrieved from http://hakielimu.org/files/publications/Does \%20School\%20 Environment \%20Affect \%20Student\%20Achievement.pdf

Juan, A. and Visser, M. (2017). Home and school environmental determinants of science achievement of South African students.
South African Journal of Education 37 (1)1292.

Korir, D.K and Kipkemboi, K. (2014).The Impact of School Environment and Peer Influences on Students' Academic Performance in Vihiga County, Kenya. Journal of Education and Practice 5, (11)3-11.

Kurniawan, J., Effendi, Z.M, and Dwita, S. (2018).The Effect of School Environment, Family Environment and Learning Motivation on Students' Learning Performance.1st International Conference On Economics Education, Economics, Business and Management, Accounting and Entrepreneurship (PICEEBA 2018). Advances in Economics, Business and Management Research, volume 57.

Leaning Liftoff, (2016). How a School's Learning Environment Affects Student Achievement. Retrieved from https://www.learningliftoff.com/how-aschools-learning-environment- affectsstudent-achievement/.

Lee, S. (2014). An Exploration of Learning Environmental Factors Affecting Student Cognitive Engagement: Implications for Instructional Design Research. Educational Technology International Journal 15 (2), 143-170.

Mege, C.A. (2014). Influence of School Environmental factors on Teaching-Learning process in Public Primary Schools in lower Nyokal division, Homa-bay district, Kenya. Master's Thesis, University of Nairobi.

Mugenda, O.M. \&Mugenda, A.G. (1999). Research Methods: Quantitative and Qualitative Approaches. Nairobi: African Center for Technology Studies.

Ministry of Education, Guyana (2016). Importance of Environment in the Classroom. Retrieved fromttps://www.education.gov.gy/web/ index.php/teachers/tips-for- teaching/ item/2074-importance-of-environment -inthe-classroom. 
Mustapha etal., (2014)..Environmental Factors and Students Learning Approaches: A Survey on Malaysian Polytechnics Students. Retrieved from https://www. researchgate.net / publication/287545366 Environmental_ Factors_and_Students_Learning_Approache s_A_Survey_on_Malaysian_Polytechnics_St udents

Mwinuka, V.J. (2016). The quality of teachers and school performance in urban and rural secondary schools in Monduli District, Tanzania. Master's Thesis. The Open University of Tanzania.

Nambuya, O.B. (2013). School based Factors influencing Student's Academic Performance at Kenya certificate of Secondary Education in Teso South District. Master's Thesis. University of Nairobi.

Namugaanyi, G. (2012). The influence of school environment on students' academic performance in selected secondary schools in Luwero District. Makerere University. Retrieved from http://makir.mak. ac.ug/handle/10570/3811.

Ngussa, B.M. and Nzowa, G. (2019). Correlation between Parental Involvement and Students' Commitment toward Learning: A Case of Secondary Schools in Arusha District, Tanzania. International Journal of Research and Innovation in Social Sciences (IJRISS) III (V), 121-128.

Nyoni, M., Nyoni, T. and Bonga, W.G. (2017).Factors Affecting Students' Academic Achievement in Zimbabwe's Rural Secondary Schools: A Case Study of Marimasimbe Secondary School in Jiri Community. Journal of Economics and Finance (DRJ-JEF) 2 (3), 0115.
Oblinger, D. (2010).A Commitment to Learning: Attention, Engagement, and the Next Generation. Retrieved from https://er.educause.edu/ articles/ 2010/10/a-commitment-to-learningattention-engagement-and-the-nextgeneration.

Oden, C. (2019). Influence of School environment on the Academic Performance of Secondary school students in Nigeria. Retrieved from https://www. Projecttopics . org /influence$\mathrm{s}$ chool-environment-a cademicperformance-secondary-school-studentsnigeria.html .

Ulugumu, W.S. (2016). The influence of home and school environment on students' Academic Performance: A case study of Wanging'ombe District, Tanzania. Master's Thesis, Open University of Tanzania.

UNESCO, (2016). School resources and learning environment in Africa. Key results from a regional survey on factors affecting quality of education. Retrieved from http://uis.unesco.org/sites/default/files/sch ool-resources-and-learning-environment-inafrica-2016-en/school-resources-andlearning-environment-in-africa-2016-en.pdf

Usaini, I., Abubakar, N. B. and Bichi, A. B. (2015). Influence of school environment on academic performance of secondary school students in Kuala Terengganu, Malaysia. https://www.researchgate.net/publication/ 305659360_influence_of_school_environm ent_on_academic_performance_of_second ary_school_students_in_kuala_terengganu_ malay sia. 